\title{
Influence of protonation on the properties derived from electron density
}

\author{
Ibon Alkorta*and Óscar Picazo \\ Instituto de Química Médica, CSIC, Juan de la Cierva 3, E-28006 Madrid, Spain \\ E-mail: ibon@iqm.csic.es
}

Dedicated to Professor José Elguero on his $70^{\text {th }}$ anniversary and

for all these years of guidance and teaching. Thanks Pepe

(received 13 Jan 05; accepted 12 Apr 05; published on the web 14 Apr 05)

\begin{abstract}
The effect of protonation on the electron density of a series of small molecules has been studied by means of the quantum theory of the Atoms in Molecules (QTAIM) methodology. The nonuniform redistribution of the electron density upon protonation of the systems produces an increase of the atomic energy of the protonated heteroatom and a reduction of the atomic charge for the protonated oxygen, while an increase of the charge on the protonated nitrogens is observed. The total volume of the protonated systems is smaller than that of the corresponding neutral ones. Thus, all the groups that form the molecule suffer a reduction of the volume when the systems become protonated. The transferability of the methyl group properties between the molecules studied has been analyzed.
\end{abstract}

Keywords: QTAIM, Protonation, atomic properties, DFT calculations

\section{Introduction}

Protonation is one of the simplest chemical processes that produce significant alterations in the molecular properties. The chemical and biological properties of the neutral and protonated species are in many cases dramatically different.

The Quantum Theory of Atoms In Molecules (QTAIM) provides a tool to analyze the electron density of the molecule and define a unique volume for each atom, named as the atomic basin. Integration within the atomic basin allows one to obtain the atomic contribution to the whole molecule. Thus the molecular properties can be divided into atomic contributions. Thus, the important changes due to the protonation of a given molecules can be attributed to changes in the individual atomic properties. 
In the present article, the atomic properties (energy, charge and volume) of a series of neutral- and the corresponding protonated- molecules have been calculated by using the QTAIM methodology. A comparison of the changes upon protonation has been carried out.

\section{Methods}

The geometries of all the systems have been optimized at the B3LYP/6-31G* computational level $^{1,2}$ within the Gaussian-98 package. $^{3}$ Their minimum nature has been confirmed by frequency calculation at the same computational level. The energies have been corrected with the unscaled Zero Point Energy (ZPE) values.

The systems selected have been chosen based on their simplicity and the importance of the corresponding chemical group in organic chemistry.

The electron density has been analyzed by using the QTAIM methodology ${ }^{4}$ with the Aimpac set of programs. ${ }^{5}$ In all cases the PROAIM algorithm has been used for the atomic integration. The QTAIM provides a topological analysis of the electron density that allows to characterize unique atomic regions, atomic basins. The integration within those regions provides atomic properties, such as charge and energy. The sum of the atomic properties within a given molecule should be equal to that obtained for the whole molecule.

As a measure of the quality of the numerical integration, three parameters can be considered: two corresponding to molecular parameters are defined as the differences between the total charge and energy for each system obtained in the quantum calculation, and as a sum of the atomic contributions. The third parameter corresponds to the values of the integrated Laplacian in each atomic basin. Ideally all these three parameter should be close to zero.

\section{Results and Discussion}

The systems considered are shown in Figure 1, with the numbering used in the present article. In two cases $\left[\left(\mathrm{CH}_{3}\right) \mathrm{HCOH}^{+}\right.$and $\left.\left(\mathrm{CH}_{3}\right) \mathrm{HCNH}\right]$ two possible isomers for the same structure can be considered. In both cases, the one with the hydrogen atom attached to the heteroatom in the position trans- to the methyl group is the more stable one, by 1.8 and $1.3 \mathrm{~kJ} / \mathrm{mol}$, respectively. In these cases, only the most stable structure has been considered. 
<smiles>O</smiles><smiles>COC</smiles><smiles>CN</smiles><smiles>CN(C)C</smiles><smiles>CC(=O)C=O</smiles><smiles>C=NC</smiles><smiles>CC(C)=N[Hg]</smiles><smiles>O</smiles><smiles>[2H]OC</smiles><smiles>[1H]N</smiles><smiles>CNC</smiles><smiles>C=O</smiles><smiles>CC(C)=O</smiles>
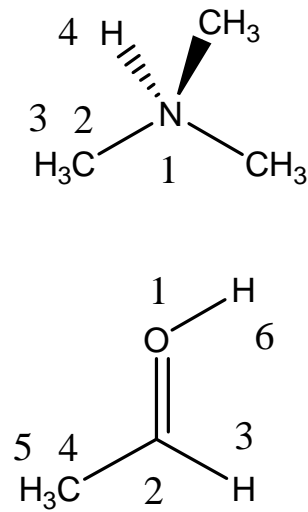<smiles></smiles><smiles>C=N</smiles>

5

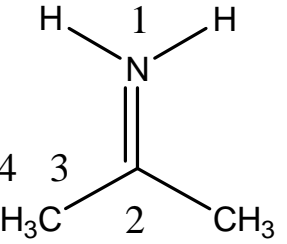<smiles>CO</smiles><smiles>[1H]N</smiles><smiles>[2H]C(C)C</smiles><smiles>C=O</smiles><smiles>CC(C)=O</smiles><smiles>C=NC</smiles>

Figure 1. Compounds studied, with the numbering used in the present article. 
The calculated and experimental proton affinities of the systems considered are gathered in Table 1. The largest deviations correspond to the imine derivatives studied here (20 to $33 \mathrm{~kJ} / \mathrm{mol}$ ), while in the rest of the cases the absolute value of the deviations are smaller than $15 \mathrm{~kJ} / \mathrm{mol}$. These results can be considered as acceptable, taking into account the computational level used and the fact that the main purpose of this article is the study of the electron density of the neutral and protonated species.

Table 1. Calculated and experimental proton affinities (PA) in $\mathrm{kJ} / \mathrm{mol}$. The symmetry of the optimized neutral and protonated systems is shown

\begin{tabular}{lcccc}
\hline & $\begin{array}{c}\text { Symmetry } \\
\text { Neutral/protonated }\end{array}$ & Calculated & Experimental & \\
& $\mathrm{C} 2 \mathrm{v} / \mathrm{C} 3 \mathrm{v}$ & 700.97 & 691 & 9.97 \\
$\mathrm{H}_{2} \mathrm{O} / \mathrm{H}_{3} \mathrm{O}^{+}$ & $\mathrm{Cs} / \mathrm{Cs}$ & 757.30 & 754.3 & 3.00 \\
$\mathrm{CH}_{3} \mathrm{OH} / \mathrm{CH}_{3} \mathrm{OH}_{2}{ }^{+}$ & $\mathrm{C} 2 \mathrm{v} / \mathrm{Cs}$ & 787.52 & 792 & -4.48 \\
$\left(\mathrm{CH}_{3}\right)_{2} \mathrm{O} /\left(\mathrm{CH}_{3}\right)_{2} \mathrm{OH}^{+}$ & $\mathrm{C} \mathrm{v} / \mathrm{T} \mathrm{D}$ & 868.02 & 853.6 & 14.42 \\
$\mathrm{NH}_{3} / \mathrm{NH}_{4}{ }^{+}$ & $\mathrm{Cs} / \mathrm{C} \mathrm{v}$ & 909.21 & 899.00 & 10.21 \\
$\mathrm{CH}_{3} \mathrm{NH}_{2} / \mathrm{CH}_{3} \mathrm{NH}_{3}{ }^{+}$ & $\mathrm{Cs} / \mathrm{C} 2 \mathrm{v}$ & 933.56 & 929.5 & 4.06 \\
$\left(\mathrm{CH}_{3}\right)_{2} \mathrm{NH} /\left(\mathrm{CH}_{3}\right)_{2} \mathrm{NH}_{2}{ }^{+}$ & $\mathrm{C} \mathrm{v} / \mathrm{C} 3 \mathrm{v}$ & 947.79 & 948.9 & -1.11 \\
$\left(\mathrm{CH}_{3}\right)_{3} \mathrm{~N} /\left(\mathrm{CH}_{3}\right)_{3} \mathrm{NH}^{+}$ & $\mathrm{C} 2 \mathrm{v} / \mathrm{Cs}$ & 704.12 & 712.9 & -8.78 \\
$\mathrm{H}_{2} \mathrm{CO} / \mathrm{H}_{2} \mathrm{COH}$ & $\mathrm{Cs} / \mathrm{Cs}$ & 771.27 & 768.5 & 2.77 \\
$\left(\mathrm{CH}_{3}\right) \mathrm{HCO} /\left(\mathrm{CH}_{3}\right) \mathrm{HCOH}^{+}$ & $\mathrm{C} 2 \mathrm{v} / \mathrm{Cs}$ & 816.85 & 812 & 4.85 \\
$\left(\mathrm{CH}_{3}\right)_{2} \mathrm{CO} /\left(\mathrm{CH}_{3}\right)_{2} \mathrm{COH}^{+}$ & $\mathrm{Cs} / \mathrm{C} 2 \mathrm{v}$ & 872.99 & 852.9 & $\mathbf{2 0 . 0 9}$ \\
$\mathrm{H}_{2} \mathrm{CNH} / \mathrm{H}_{2} \mathrm{CNH}_{2}{ }^{+}$ & $\mathrm{Cs} / \mathrm{Cs}$ & 918.81 & 885.1 & 33.71 \\
$\left(\mathrm{CH}_{3}\right) \mathrm{HCNH} /\left(\mathrm{CH}_{3}\right) \mathrm{HCNH}_{2}{ }^{+}$ & $\mathrm{Cs} / \mathrm{C} 1$ & 954.00 & 932.3 & $\mathbf{2 1 . 7 0}$ \\
$\left(\mathrm{CH}_{3}\right)_{2} \mathrm{CNH} /\left(\mathrm{CH}_{3}\right)_{2} \mathrm{CNH}_{2}{ }^{+}$ & & & & \\
\hline
\end{tabular}

The three parameters used to measure the fitness of the atomic partition for all the systems considered are given in Table 2. The error found in the energetic partition is very good, since in only two cases is it larger that $1 \mathrm{~kJ} / \mathrm{mol}$, and the average is only $0.33 \mathrm{~kJ} / \mathrm{mol}$. The maximum charge-deviation is 0.003 e with an average of 0.0006 e. The integrated Laplacian is only larger than 1 E-03 in five cases. In general, the errors indicate that the partition nicely represents the molecular properties with minimum deviations with respect to the whole molecule. In any case, it is significant that the largest errors in the three parameters are found in the same compound. 
Table 2. Errors obtained in the energy and charge partition, and the maximum value of the Laplacian within the atomic basins

\begin{tabular}{cccc}
\hline System & Error in Energy $(\mathrm{kJ} / \mathrm{mol})$ & Error in Charge $(\mathrm{e})$ & Max. $|\mathrm{L}|$ (a.u.) \\
\hline $\mathrm{H}_{2} \mathrm{O}$ & 0.01 & $1.4 \mathrm{E}-06$ & $5.6 \mathrm{E}-05$ \\
$\mathrm{H}_{3} \mathrm{O}^{+}$ & 0.01 & $-2.6 \mathrm{E}-07$ & $5.9 \mathrm{E}-05$ \\
$\mathrm{CH}_{3} \mathrm{OH}$ & 0.22 & $-1.8 \mathrm{E}-04$ & $4.0 \mathrm{E}-04$ \\
$\mathrm{CH}_{3} \mathrm{OH}_{2}^{+}$ & 0.21 & $-1.6 \mathrm{E}-04$ & $4.0 \mathrm{E}-04$ \\
$\left(\mathrm{CH}_{3}\right)_{2} \mathrm{O}$ & -0.12 & $1.8 \mathrm{E}-04$ & $4.4 \mathrm{E}-04$ \\
$\left(\mathrm{CH}_{3}\right)_{2} \mathrm{OH}^{+}$ & -0.28 & $4.6 \mathrm{E}-04$ & $9.5 \mathrm{E}-04$ \\
$\mathrm{NH}_{3}$ & 0.01 & $-1.6 \mathrm{E}-05$ & $1.3 \mathrm{E}-04$ \\
$\mathrm{NH}_{4}^{+}$ & -0.02 & $2.3 \mathrm{E}-06$ & $1.0 \mathrm{E}-04$ \\
$\mathrm{CH}_{3} \mathrm{NH}_{2}$ & 0.20 & $-6.4 \mathrm{E}-04$ & $2.5 \mathrm{E}-04$ \\
$\mathrm{CH}_{3} \mathrm{NH}_{3}^{+}$ & 0.18 & $-2.2 \mathrm{E}-04$ & $4.5 \mathrm{E}-04$ \\
$\left(\mathrm{CH}_{3}\right)_{2} \mathrm{NH}^{+}$ & -0.97 & $1.4 \mathrm{E}-03$ & $1.1 \mathrm{E}-03$ \\
$\left(\mathrm{CH}_{3}\right)_{2} \mathrm{NH}_{2}^{+}$ & -0.48 & $6.8 \mathrm{E}-04$ & $3.3 \mathrm{E}-04$ \\
$\left(\mathrm{CH}_{3}\right)_{3} \mathrm{~N}$ & -0.07 & $2.3 \mathrm{E}-04$ & $7.5 \mathrm{E}-04$ \\
$\left(\mathrm{CH}_{3}\right)_{3} \mathrm{NH}^{+}$ & 0.26 & $-1.8 \mathrm{E}-03$ & $7.8 \mathrm{E}-04$ \\
$\mathrm{H}_{2} \mathrm{CO}$ & -0.01 & $7.3 \mathrm{E}-05$ & $3.6 \mathrm{E}-05$ \\
$\mathrm{H}_{2} \mathrm{COH}$ & $-6.1 \mathrm{E}-05$ & $2.1 \mathrm{E}-04$ \\
$\left(\mathrm{CH}_{3}\right) \mathrm{HCO}^{+}$ & 0.13 & $-7.2 \mathrm{E}-04$ & $7.4 \mathrm{E}-04$ \\
$\left(\mathrm{CH}_{3}\right) \mathrm{HCOH}^{+}$ & 0.46 & $-2.5 \mathrm{E}-03$ & $1.5 \mathrm{E}-03$ \\
$\left(\mathrm{CH}_{3}\right)_{2} \mathrm{CO}$ & 1.34 & $-1.7 \mathrm{E}-03$ & $1.2 \mathrm{E}-03$ \\
$\left(\mathrm{CH}_{3}\right)_{2} \mathrm{COH}^{+}$ & -0.51 & $-2.7 \mathrm{E}-03$ & $2.2 \mathrm{E}-03$ \\
$\mathrm{H}_{2} \mathrm{CNH}^{+}$ & 0.84 & $3.2 \mathrm{E}-05$ & $1.4 \mathrm{E}-04$ \\
$\mathrm{H}_{2} \mathrm{CNH}_{2}^{+}$ & -0.04 & $4.6 \mathrm{E}-05$ & $4.6 \mathrm{E}-05$ \\
$\left(\mathrm{CH}_{3}\right)_{\mathrm{HCNH}}$ & -0.05 & $-4.0 \mathrm{E}-05$ & $3.4 \mathrm{E}-04$ \\
$\left(\mathrm{CH}_{3}\right) \mathrm{HCNH}_{2}{ }^{+}$ & 0.05 & $5.0 \mathrm{E}-05$ & $4.9 \mathrm{E}-04$ \\
$\left(\mathrm{CH}_{3}\right)_{2} \mathrm{CNH}^{+}$ & -0.15 & $-3.0 \mathrm{E}-03$ & $3.6 \mathrm{E}-03$ \\
$\left(\mathrm{CH}_{3}\right)_{2} \mathrm{CNH}_{2}{ }^{+}$ & 2.08 & $-1.3 \mathrm{E}-04$ & $4.6 \mathrm{E}-04$ \\
\hline & 0.34 & & \\
\hline
\end{tabular}

The representation of the error in energy value $v s$ the charge error or maximum value of the Laplacian (Figure 2) clearly shows that the three parameters provide similar information on the fitness of the atomic integration, as if the quantification of only one of them is enough to measure the quality of the partition. 


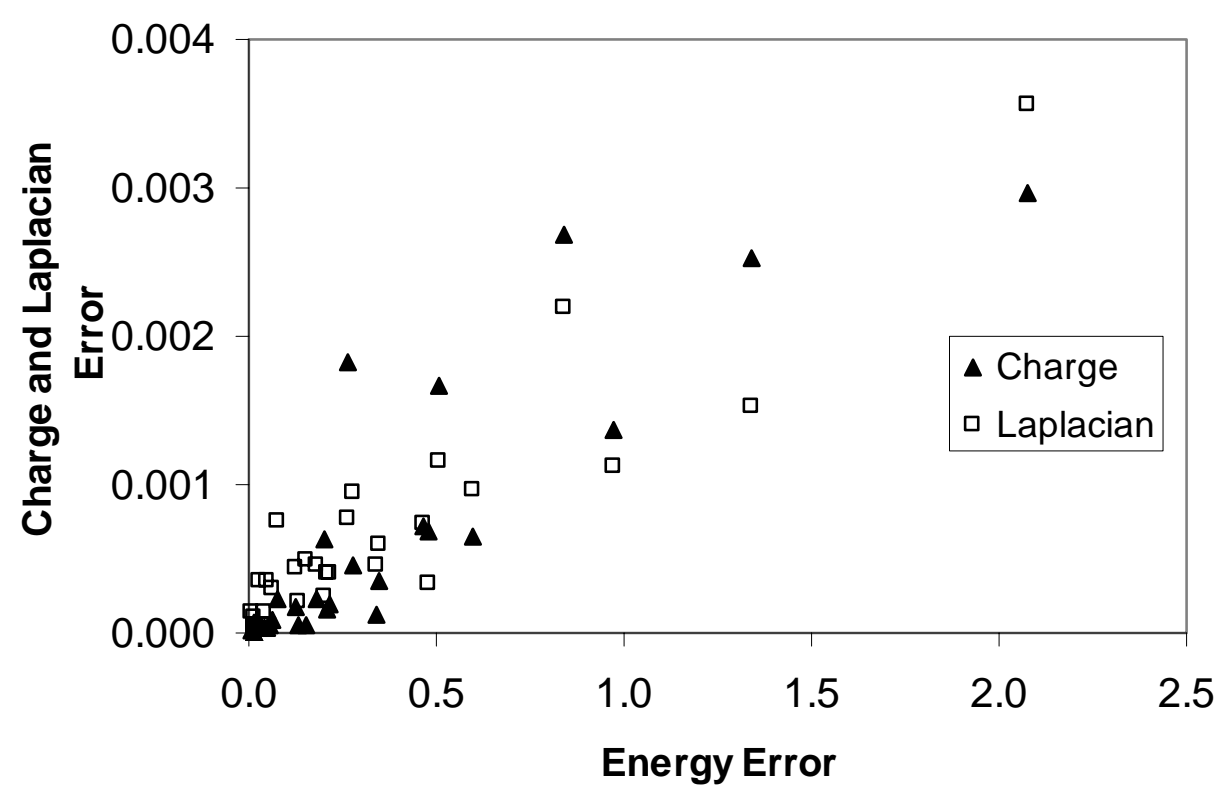

Figure 2. Error in the total energy $(\mathrm{kJ} / \mathrm{mol})$ vs error in the molecular charge error $(e)$ and maximum value of the integrated Laplacian (a.u.).

The integrated atomic properties are collected in Tables 3, 4 and 6. For simplicity, the values for the hydrogen atoms of the methyl groups and other analogous groups have been averaged, and in the symmetric cases only one atom has been listed (a full list of these properties can be obtained from the authors on request).

The energetic gain due to protonation is redistributed along the molecular structure in a nonuniform way (Table 3). The proton atom, which in isolation shows zero electronic energy, can contribute up to $1151 \mathrm{~kJ} / \mathrm{mol}$ to the total molecular energy in the case of trimethylamine. The heteroatom being protonated is stabilized in all the cases, with the exception of the oxygen atom of the dimethyl ether molecule $\left[\left(\mathrm{CH}_{3}\right)_{2} \mathrm{O}\right]$. This stabilization decreases with the number of methyl groups present in the molecule. In all the families, the stabilization energy of the protonated atoms shows a correlation with the number of methyl groups attached to them (Fig. $3)$.

For the methyl groups, the carbon atoms are stabilized while the hydrogens are destabilized. The overall results are a stabilization of the methyl group in the dimethyl ether and methanol while a destabilization is observed in the other cases. 
Table 3. Atomic energy (Hartrees) and variation $(\mathrm{kJ} / \mathrm{mol})$ upon protonation

\begin{tabular}{|c|c|c|c|c|c|c|}
\hline System & Atom & Total energy & System & Atom & Total energy & Variation \\
\hline \multirow{2}{*}{$\mathrm{H}_{2} \mathrm{O}$} & O-1 & -75.65965 & $\mathrm{H}_{3} \mathrm{O}^{+}$ & O-1 & -75.85207 & -505.2 \\
\hline & $\mathrm{H}-2$ & -0.37465 & & $\mathrm{H}-2$ & -0.27900 & 251.1 \\
\hline \multirow[t]{4}{*}{$\mathrm{CH}_{3} \mathrm{OH}$} & O-1 & -75.77938 & $\mathrm{CH}_{3} \mathrm{OH}_{2}^{+}$ & O-1 & -75.84527 & -173.0 \\
\hline & $\mathrm{H}-2$ & -0.38435 & & $\mathrm{H}-2$ & -0.30120 & 218.3 \\
\hline & C-3 & -37.69785 & & C-3 & -37.88502 & -491.4 \\
\hline & $\mathrm{H}-4$ & -0.61758 & & $\mathrm{H}-4$ & -0.56099 & 148.6 \\
\hline \multirow[t]{4}{*}{$\left(\mathrm{CH}_{3}\right)_{2} \mathrm{O}$} & O-1 & -75.87723 & $\left(\mathrm{CH}_{3}\right)_{2} \mathrm{OH}^{+}$ & O-1 & -75.85171 & 67.0 \\
\hline & C-2 & -37.72839 & & C-2 & -37.87647 & -388.8 \\
\hline & $\mathrm{H}-3$ & -0.61518 & & H-3 & -0.56903 & 121.2 \\
\hline & & & & $\mathrm{H}-4$ & -0.31943 & \\
\hline \multirow[t]{2}{*}{$\mathrm{NH}_{3}$} & $\mathrm{~N}-1$ & -55.11896 & $\mathrm{NH}_{4}^{+}$ & $\mathrm{N}-1$ & -55.35376 & -616.5 \\
\hline & $\mathrm{H}-2$ & -0.47633 & & $\mathrm{H}-2$ & -0.38503 & 239.7 \\
\hline \multirow[t]{4}{*}{$\mathrm{CH}_{3} \mathrm{NH}_{2}$} & $\mathrm{~N}-1$ & -55.17289 & $\mathrm{CH}_{3} \mathrm{NH}_{3}+$ & $\mathrm{N}-1$ & -55.34126 & -442.1 \\
\hline & $\mathrm{H}-2$ & -0.48602 & & $\mathrm{H}-2$ & -0.40539 & 211.7 \\
\hline & C-3 & -37.85058 & & C-3 & -37.94282 & -242.2 \\
\hline & $\mathrm{H}-4$ & -0.61921 & & $\mathrm{H}-4$ & -0.57151 & 125.2 \\
\hline \multirow[t]{4}{*}{$\left(\mathrm{CH}_{3}\right)_{2} \mathrm{NH}$} & $\mathrm{N}-1$ & -55.21864 & $\left(\mathrm{CH}_{3}\right)_{2} \mathrm{NH}_{2}^{+}$ & $\mathrm{N}-1$ & -55.33487 & -305.2 \\
\hline & $\mathrm{H}-2$ & -0.49261 & & $\mathrm{H}-2$ & -0.42304 & 182.7 \\
\hline & C-3 & -37.87324 & & C-3 & -37.94707 & -193.8 \\
\hline & $\mathrm{H}-4$ & -0.61758 & & $\mathrm{H}-4$ & -0.57652 & 107.8 \\
\hline \multirow[t]{4}{*}{$\left(\mathrm{CH}_{3}\right)_{3} \mathrm{~N}$} & $\mathrm{~N}-1$ & -55.25613 & $\left(\mathrm{CH}_{3}\right)_{3} \mathrm{NH}^{+}$ & $\mathrm{N}-1$ & -55.31763 & -161.5 \\
\hline & C-2 & -37.88980 & & $\mathrm{C}-2$ & -37.95525 & -171.8 \\
\hline & $\mathrm{H}-3$ & -0.61654 & & $\mathrm{H}-3$ & -0.58103 & 93.2 \\
\hline & & & & $\mathrm{H}-4$ & -0.43827 & \\
\hline \multirow[t]{4}{*}{$\mathrm{H}_{2} \mathrm{CO}$} & O-1 & -75.97167 & $\mathrm{H}_{2} \mathrm{COH}^{+}$ & O-1 & -75.99326 & -56.7 \\
\hline & C-2 & -37.32325 & & $\mathrm{C}-2$ & -37.44769 & -326.7 \\
\hline & $\mathrm{H}-3$ & -0.60278 & & $\mathrm{H}-3$ & -0.51912 & 219.6 \\
\hline & & & & $\mathrm{H}-4$ & -0.30326 & \\
\hline \multirow[t]{6}{*}{$\left(\mathrm{CH}_{3}\right) \mathrm{HCO}$} & O-1 & -76.00844 & $\left(\mathrm{CH}_{3}\right) \mathrm{HCOH}^{+}$ & O-1 & -76.01740 & -23.5 \\
\hline & C-2 & -37.34039 & & C-2 & -37.53074 & -499.8 \\
\hline & $\mathrm{H}-3$ & -0.60948 & & H-3 & -0.54566 & 167.6 \\
\hline & C-4 & -38.08869 & & $\mathrm{C}-4$ & -38.08850 & 0.5 \\
\hline & H-5 & -0.59400 & & H-5 & -0.54644 & 124.9 \\
\hline & & & & H-6 & -0.31458 & \\
\hline
\end{tabular}


Table 3. Continued

\begin{tabular}{|c|c|c|c|c|c|c|}
\hline System & Atom & Total energy & System & Atom & Total energy & Variation \\
\hline \multirow[t]{5}{*}{$\left(\mathrm{CH}_{3}\right)_{2} \mathrm{CO}$} & O-1 & -76.03182 & $\left(\mathrm{CH}_{3}\right)_{2} \mathrm{COH}^{+}$ & O-1 & -76.03569 & -10.2 \\
\hline & $\mathrm{C}-2$ & -37.34547 & & $\mathrm{C}-2$ & -37.56653 & -580.4 \\
\hline & $\mathrm{C}-3$ & -38.09362 & & C-3 & -38.09722 & -9.5 \\
\hline & $\mathrm{H}-4$ & -0.59900 & & $\mathrm{H}-4$ & -0.55953 & 103.6 \\
\hline & & & & $\mathrm{H}-5$ & -0.32516 & \\
\hline \multirow[t]{4}{*}{$\mathrm{H}_{2} \mathrm{CNH}$} & $\mathrm{N}-1$ & -55.38239 & $\mathrm{H}_{2} \mathrm{CNH}_{2}^{+}$ & $\mathrm{N}-1$ & -55.54159 & -418.0 \\
\hline & $\mathrm{C}-2$ & -37.54841 & & $\mathrm{C}-2$ & -37.58943 & -107.7 \\
\hline & $\mathrm{H}-3$ & -0.60426 & & H-3 & -0.53192 & 189.9 \\
\hline & $\mathrm{H}-4$ & -0.48790 & & $\mathrm{H}-4$ & -0.38963 & 258.0 \\
\hline \multirow[t]{6}{*}{$\left(\mathrm{CH}_{3}\right) \mathrm{HCNH}$} & $\mathrm{N}-1$ & -55.40669 & $\left(\mathrm{CH}_{3}\right) \mathrm{HCNH}_{2}^{+}$ & $\mathrm{N}-1$ & -55.54567 & -364.9 \\
\hline & $\mathrm{C}-2$ & -37.55982 & & C-2 & -37.63057 & -185.8 \\
\hline & $\mathrm{H}-3$ & -0.61390 & & $\mathrm{H}-3$ & -0.55222 & 162.0 \\
\hline & C-4 & -38.08005 & & C-4 & -38.10234 & -58.5 \\
\hline & H-5 & -0.60100 & & H-5 & -0.56300 & 99.8 \\
\hline & H-6 & -0.48982 & & H-6 & -0.39900 & 238.4 \\
\hline \multirow[t]{5}{*}{$\left(\mathrm{CH}_{3}\right)_{2} \mathrm{CNH}$} & $\mathrm{N}-1$ & -55.41433 & $\left(\mathrm{CH}_{3}\right)_{2} \mathrm{CNH}_{2}^{+}$ & $\mathrm{N}-1$ & -55.55078 & -358.3 \\
\hline & $\mathrm{C}-2$ & -37.56216 & & $\mathrm{C}-2$ & -37.64458 & -216.4 \\
\hline & C-3 & -38.08942 & & $\mathrm{C}-3$ & -38.10668 & -45.3 \\
\hline & $\mathrm{H}-4$ & -0.60402 & & $\mathrm{H}-4$ & -0.57200 & 84.1 \\
\hline & H-5 & -0.49442 & & H-5 & -0.40649 & 230.9 \\
\hline
\end{tabular}

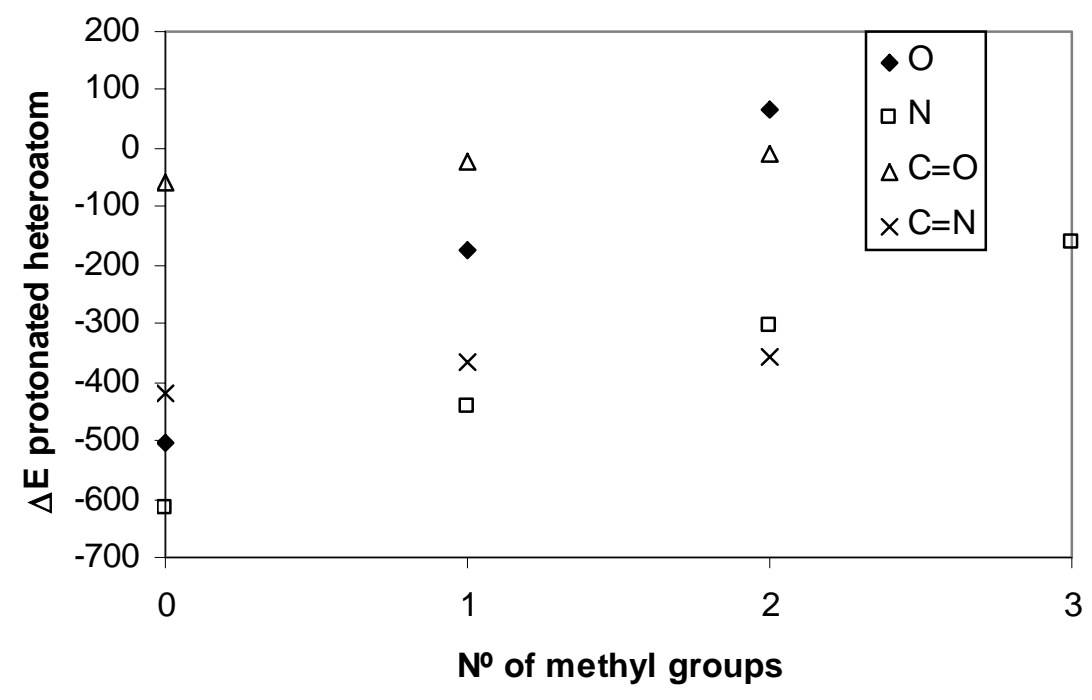

Figure 3. Energy variation $(\mathrm{kJ} / \mathrm{mol})$ of the protonated heteroatom as a function of the total number of methyl groups in the molecule. 
The calculated charges and the variations due to the protonation are shown in Table 4 . The calculated charge on the proton added to the molecules varies between $+0.70 e$ for protonated water to $+0.45 e$ for the ammonium cation. The remaining charge up to $+1.0 e$ should be distributed in the rest of the molecule. The protonation on the oxygen atom produces a reduction in the electron density of this atom in both dimethyl ether and the carbonyl derivatives studied here, while the opposite is found for the nitrogen compounds, where a gain is observed. Increasing methyl substitution produces a reduction of the charge variation on the protonated heteroatom with respect to the unsubstituted derivatives, with the exception of the imine compounds (Figure 4). For methyl groups, there is an overall loss of electronic density, although in some cases the carbon atoms show an increase of density, as the loss by hydrogen atoms compensates the overall molecular density.

Table 4. Calculated atomic charges (e) and variation upon protonation

\begin{tabular}{ccccccc}
\hline System & Atom & Charge & System & Atom & Charge & Variation \\
\hline $\mathrm{H}_{2} \mathrm{O}$ & $\mathrm{O}-1$ & -1.093 & $\mathrm{H}_{3} \mathrm{O}^{+}$ & $\mathrm{O}-1$ & -1.092 & 0.002 \\
& $\mathrm{H}-2$ & 0.547 & & $\mathrm{H}-2$ & 0.697 & 0.151 \\
$\mathrm{CH}_{3} \mathrm{OH}$ & $\mathrm{O}-1$ & -1.073 & $\mathrm{CH}_{3} \mathrm{OH}_{2}{ }^{+}$ & $\mathrm{O}-1$ & -1.038 & 0.035 \\
& $\mathrm{H}-2$ & 0.541 & & $\mathrm{H}-2$ & 0.668 & 0.128 \\
& $\mathrm{C}-3$ & 0.491 & & $\mathrm{C}-3$ & 0.247 & -0.244 \\
& $\mathrm{H}-4$ & 0.014 & & $\mathrm{H}-4$ & 0.151 & 0.138 \\
$\left(\mathrm{CH}_{3}\right)_{2} \mathrm{O}$ & $\mathrm{O}-1$ & -1.075 & $\left(\mathrm{CH}_{3}\right)_{2} \mathrm{OH}^{+}$ & $\mathrm{O}-1$ & -0.999 & 0.077 \\
& $\mathrm{C}-2$ & 0.492 & & $\mathrm{C}-2$ & 0.282 & -0.210 \\
& $\mathrm{H}-3$ & 0.015 & & $\mathrm{H}-3$ & 0.132 & 0.116 \\
& & & & $\mathrm{H}-4$ & 0.646 & \\
$\mathrm{NH}_{3}$ & $\mathrm{~N}-1$ & -1.039 & $\mathrm{NH}_{4}{ }^{+}$ & $\mathrm{N}-1$ & -1.081 & -0.042 \\
& $\mathrm{H}-2$ & 0.346 & & $\mathrm{H}-2$ & 0.520 & 0.174 \\
$\mathrm{CH}_{3} \mathrm{NH}{ }_{2}$ & $\mathrm{~N}-1$ & -1.013 & $\mathrm{CH}_{3} \mathrm{NH}_{3}^{+}$ & $\mathrm{N}-1$ & -1.049 & -0.037 \\
& $\mathrm{H}-2$ & 0.339 & & $\mathrm{H}-2$ & 0.490 & 0.151 \\
& $\mathrm{C}-3$ & 0.318 & & $\mathrm{C}-3$ & 0.214 & -0.104 \\
& $\mathrm{H}-4$ & 0.005 & & $\mathrm{H}-4$ & 0.121 & 0.116 \\
& $\mathrm{~N}-1$ & -1.002 & $\left(\mathrm{CH}_{3}\right)_{2} \mathrm{NH}_{2}^{+}$ & $\mathrm{N}-1$ & -1.029 & -0.026 \\
& $\mathrm{H}-2$ & 0.337 & & $\mathrm{H}-2$ & 0.466 & 0.129 \\
$\left(\mathrm{CH}_{3}\right)_{2} \mathrm{NH}$ & $\mathrm{C}-3$ & 0.318 & & $\mathrm{C}-3$ & 0.223 & -0.096 \\
& $\mathrm{H}-4$ & 0.005 & & $\mathrm{H}-4$ & 0.109 & 0.104 \\
& $\mathrm{~N}-1$ & -0.999 & $\left(\mathrm{CH}_{3}\right)_{3} \mathrm{NH}^{+}$ & $\mathrm{N}-1$ & -1.010 & -0.010 \\
& $\mathrm{C}-2$ & 0.316 & & $\mathrm{C}-2$ & 0.225 & -0.091 \\
& $\mathrm{H}-3$ & 0.006 & & $\mathrm{H}-3$ & 0.098 & 0.093 \\
& & & & $\mathrm{H}-4$ & 0.446 & \\
\hline & & & & & &
\end{tabular}


Table 4. Continued

\begin{tabular}{|c|c|c|c|c|c|c|}
\hline System & Atom & Charge & System & Atom & Charge & Variation \\
\hline \multirow[t]{4}{*}{$\mathrm{H}_{2} \mathrm{CO}$} & O-1 & -1.114 & $\mathrm{H}_{2} \mathrm{COH}^{+}$ & O-1 & -1.056 & 0.058 \\
\hline & $\mathrm{C}-2$ & 1.036 & & C-2 & 0.902 & -0.134 \\
\hline & H-3 & 0.039 & & H-3 & 0.244 & 0.204 \\
\hline & & & & $\mathrm{H}-4$ & 0.667 & \\
\hline \multirow[t]{6}{*}{$\mathrm{CH}_{3} \mathrm{CHO}$} & O-1 & -1.144 & $\mathrm{CH}_{3} \mathrm{CHOH}^{+}$ & O-1 & -1.081 & 0.063 \\
\hline & $\mathrm{C}-2$ & 1.047 & & C-2 & 0.808 & -0.239 \\
\hline & $\mathrm{H}-3$ & 0.023 & & H-3 & 0.189 & 0.167 \\
\hline & C-4 & -0.064 & & C-4 & -0.027 & 0.037 \\
\hline & H-5 & 0.046 & & H-5 & 0.152 & 0.107 \\
\hline & & & & H-6 & 0.652 & \\
\hline \multirow[t]{5}{*}{$\left(\mathrm{CH}_{3}\right)_{2} \mathrm{CO}$} & O-1 & -1.162 & $\left(\mathrm{CH}_{3}\right)_{2} \mathrm{COH}^{+}$ & O-1 & -1.092 & 0.070 \\
\hline & $\mathrm{C}-2$ & 1.056 & & C-2 & 0.765 & -0.291 \\
\hline & C-3 & -0.063 & & C-3 & -0.038 & 0.025 \\
\hline & $\mathrm{H}-4$ & 0.039 & & $\mathrm{H}-4$ & 0.128 & 0.089 \\
\hline & & & & H-5 & 0.633 & \\
\hline \multirow[t]{4}{*}{$\mathrm{H}_{2} \mathrm{CNH}$} & N-1 & -1.178 & $\mathrm{H}_{2} \mathrm{CNH}_{2}^{+}$ & N-1 & -1.237 & -0.059 \\
\hline & $\mathrm{C}-2$ & 0.757 & & C-2 & 0.775 & 0.018 \\
\hline & $\mathrm{H}-3$ & 0.041 & & H-3 & 0.212 & 0.171 \\
\hline & $\mathrm{H}-4$ & 0.339 & & $\mathrm{H}-4$ & 0.519 & 0.180 \\
\hline \multirow[t]{6}{*}{$\left(\mathrm{CH}_{3}\right) \mathrm{HC}=\mathrm{NH}$} & N-1 & -1.201 & $\left(\mathrm{CH}_{3}\right) \mathrm{HCNH}$ & N-1 & -1.249 & -0.047 \\
\hline & C-2 & 0.777 & & C-2 & 0.729 & -0.047 \\
\hline & H-3 & 0.018 & & H-3 & 0.174 & 0.156 \\
\hline & C-4 & -0.032 & & C-4 & -0.023 & 0.009 \\
\hline & H-5 & 0.035 & & H-5 & 0.121 & 0.087 \\
\hline & H-6 & 0.335 & & H-6 & 0.502 & 0.167 \\
\hline \multirow[t]{5}{*}{$\left(\mathrm{CH}_{3}\right)_{2} \mathrm{CNH}$} & $\mathrm{N}-1$ & -1.202 & $\left(\mathrm{CH}_{3}\right)_{2} \mathrm{CNH}_{2}$ & N-1 & -1.252 & -0.050 \\
\hline & C-2 & 0.791 & & C-2 & 0.702 & -0.089 \\
\hline & $\mathrm{C}-3$ & -0.041 & & $\mathrm{C}-3$ & -0.028 & 0.013 \\
\hline & $\mathrm{H}-4$ & 0.028 & & $\mathrm{H}-4$ & 0.105 & 0.077 \\
\hline & $\mathrm{H}-5$ & 0.322 & & $\mathrm{H}-5$ & 0.489 & 0.167 \\
\hline
\end{tabular}




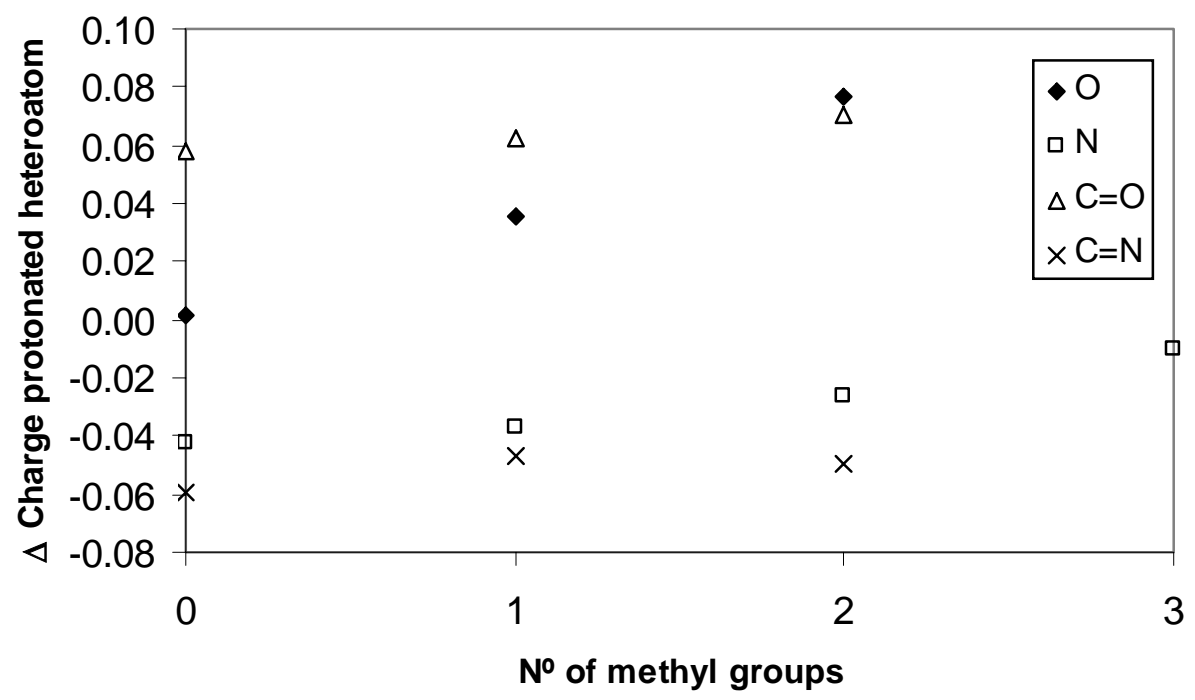

Figure 4. Charge variation upon protonation on the heteroatom vs the number of methyl groups present in the molecule.

The total volumes of the neutral and protonated species are listed in Table 5. The protonation of the molecules produces a deficiency of the electron density that compresses it towards the atomic nucleus with the corresponding reduction of the molecular volume. This variation ranges between 13.8 a.u in the water molecule to 34.2 a.u. in the trimethylamine case. The percentage reduction in the molecular volume shows a clear relationship with the Proton Affinity of the systems (Fig. 5). As the proton affinity of the systems becomes larger, the variation of the volume is smaller, as if this parameter indicates the effort of the system to accommodate to the new charged atom. Additionally, the systems can be classified according to this relationship as a function of the protonated atom (nitrogen or oxygen).

Regarding the variation of the atomic volume upon protonation (Table 6), a reduction of the volume is observed in all the atoms, except for the carbon atom of the methyl group, where a small increment is observed. Overall, the volume of the methyl group is reduced. Individually, the largest volume-reduction corresponds to the oxygen- or nitrogen atom which is protonated, up to 19.9 a.u. for the case of ammonia. 
Table 5. Total molecular volume and variation upon protonation (a.u.)

\begin{tabular}{lccc}
\hline & Neutral & Protonated & Variation \\
\hline $\mathrm{H}_{2} \mathrm{O} / \mathrm{H}_{3} \mathrm{O}^{+}$ & 177.61 & 164.02 & -13.59 \\
$\mathrm{CH}_{3} \mathrm{OH} / \mathrm{CH}_{3} \mathrm{OH}_{2}{ }^{+}$ & 346.11 & 328.74 & -17.37 \\
$\left(\mathrm{CH}_{3}\right)_{2} \mathrm{O} /\left(\mathrm{CH}_{3}\right)_{2} \mathrm{OH}^{+}$ & 514.49 & 492.27 & -22.22 \\
$\mathrm{NH}_{3} / \mathrm{NH}_{4}^{+}$ & 228.79 & 204.32 & -24.47 \\
$\mathrm{CH}_{3} \mathrm{NH}_{2} / \mathrm{CH}_{3} \mathrm{NH}_{3}{ }^{+}$ & 390.75 & 364.41 & -26.34 \\
$\left(\mathrm{CH}_{3}\right)_{2} \mathrm{NH} /\left(\mathrm{CH}_{3}\right)_{2} \mathrm{NH}_{2}{ }^{+}$ & 553.08 & 523.29 & -29.78 \\
$\left(\mathrm{CH}_{3}\right)_{3} \mathrm{~N} /\left(\mathrm{CH}_{3}\right)_{3} \mathrm{NH}^{+}$ & 712.99 & 678.83 & -34.16 \\
$\mathrm{H}_{2} \mathrm{CO} / \mathrm{H}_{2} \mathrm{COH}$ & 293.75 & 271.92 & -21.83 \\
$\left(\mathrm{CH}_{3}\right) \mathrm{HCO} /\left(\mathrm{CH}_{3}\right) \mathrm{HCOH}^{+}$ & 451.84 & 429.89 & -21.95 \\
$\left(\mathrm{CH}_{3}\right)_{2} \mathrm{CO} /\left(\mathrm{CH}_{3}\right)_{2} \mathrm{COH}^{+}$ & 606.26 & 583.98 & -22.28 \\
$\mathrm{H}_{2} \mathrm{CNH} / \mathrm{H}_{2} \mathrm{CNH}{ }_{2}^{+}$ & 337.83 & 309.36 & -28.47 \\
$\left(\mathrm{CH}_{3}\right) \mathrm{HCNH} /\left(\mathrm{CH}_{3}\right) \mathrm{HCNH}_{2}{ }^{+}$ & 495.76 & 466.83 & -28.93 \\
$\left(\mathrm{CH}_{3}\right)_{2} \mathrm{CNH} /\left(\mathrm{CH}_{3}\right)_{2} \mathrm{CNH}_{2}^{+}$ & 650.99 & 621.51 & -29.48 \\
\hline
\end{tabular}

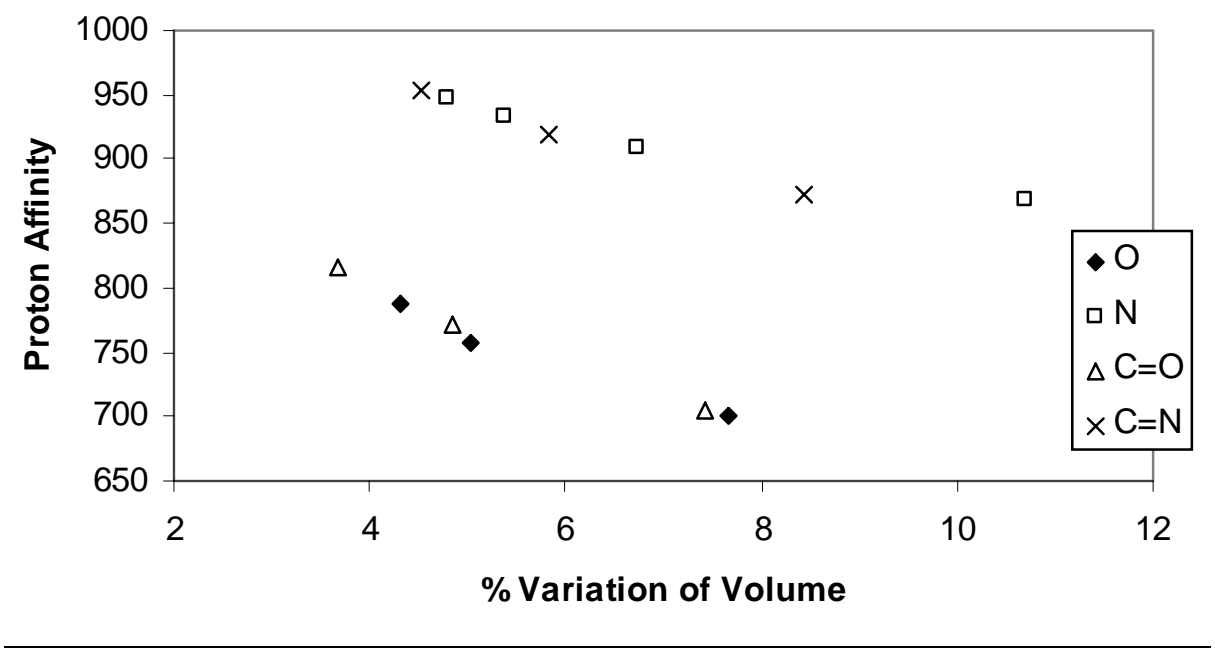

Figure 5. Variation of the molecular volume vs the proton affinity $(\mathrm{kJ} / \mathrm{mol})$. 
Table 6. Volume (a.u.) of the neutral and protonated species

\begin{tabular}{|c|c|c|c|c|c|c|}
\hline System & Atom & Volume & System & Atom & Volume & Variation \\
\hline \multirow[t]{2}{*}{$\mathrm{H}_{2} \mathrm{O}$} & O-1 & 131.6 & $\mathrm{H}_{3} \mathrm{O}^{+}$ & O-1 & 118.3 & -13.3 \\
\hline & $\mathrm{H}-2$ & 23.0 & & $\mathrm{H}-2$ & 15.3 & -7.7 \\
\hline \multirow[t]{4}{*}{$\mathrm{CH}_{3} \mathrm{OH}$} & O-1 & 113.4 & $\mathrm{CH}_{3} \mathrm{OH}_{2}^{+}$ & O-1 & 102.6 & -10.8 \\
\hline & $\mathrm{H}-2$ & 23.1 & & $\mathrm{H}-2$ & 16.6 & -6.5 \\
\hline & C-3 & 63.6 & & $\mathrm{C}-3$ & 73.2 & 9.6 \\
\hline & $\mathrm{H}-4$ & 48.7 & & $\mathrm{H}-4$ & 39.9 & -8.7 \\
\hline \multirow[t]{4}{*}{$\left(\mathrm{CH}_{3}\right)_{2} \mathrm{O}$} & O-1 & 96.8 & $\left(\mathrm{CH}_{3}\right)_{2} \mathrm{OH}^{+}$ & O-1 & 85.5 & -11.2 \\
\hline & $\mathrm{C}-2$ & 62.0 & & $\mathrm{C}-2$ & 70.8 & 8.8 \\
\hline & $\mathrm{H}-3$ & 48.9 & & $\mathrm{H}-3$ & 41.3 & -7.7 \\
\hline & & & & $\mathrm{H}-4$ & 17.6 & \\
\hline \multirow[t]{2}{*}{$\mathrm{NH}_{3}$} & N-1 & 131.1 & $\mathrm{NH}_{4}^{+}$ & N-1 & 111.2 & -19.9 \\
\hline & $\mathrm{H}-2$ & 32.6 & & $\mathrm{H}-2$ & 23.3 & -9.3 \\
\hline \multirow[t]{4}{*}{$\mathrm{CH}_{3} \mathrm{NH}_{2}$} & $\mathrm{~N}-1$ & 112.4 & $\mathrm{CH}_{3} \mathrm{NH}_{3}+$ & N-1 & 93.2 & -19.1 \\
\hline & $\mathrm{H}-2$ & 32.6 & & $\mathrm{H}-2$ & 24.7 & -7.9 \\
\hline & C-3 & 66.0 & & $\mathrm{C}-3$ & 72.3 & 6.3 \\
\hline & $\mathrm{H}-4$ & 49.0 & & $\mathrm{H}-4$ & 41.6 & -7.5 \\
\hline \multirow[t]{4}{*}{$\left(\mathrm{CH}_{3}\right)_{2} \mathrm{NH}$} & $\mathrm{N}-1$ & 95.0 & $\left(\mathrm{CH}_{3}\right)_{2} \mathrm{NH}_{2}^{+}$ & N-1 & 76.4 & -18.6 \\
\hline & $\mathrm{H}-2$ & 32.5 & & $\mathrm{H}-2$ & 25.8 & -6.7 \\
\hline & $\mathrm{C}-3$ & 64.5 & & $\mathrm{C}-3$ & 70.2 & 5.7 \\
\hline & $\mathrm{H}-4$ & 49.4 & & $\mathrm{H}-4$ & 42.5 & -7.0 \\
\hline \multirow[t]{4}{*}{$\left(\mathrm{CH}_{3}\right)_{3} \mathrm{~N}$} & $\mathrm{~N}-1$ & 79.7 & $\left(\mathrm{CH}_{3}\right)_{3} \mathrm{NH}^{+}$ & N-1 & 61.7 & -18.0 \\
\hline & C-2 & 62.7 & & $\mathrm{C}-2$ & 67.9 & 5.2 \\
\hline & $\mathrm{H}-3$ & 49.5 & & $\mathrm{H}-3$ & 43.0 & -6.5 \\
\hline & & & & $\mathrm{H}-4$ & 26.6 & \\
\hline \multirow[t]{4}{*}{$\mathrm{H}_{2} \mathrm{CO}$} & O-1 & 127.0 & $\mathrm{H}_{2} \mathrm{C}=\mathrm{OH}^{+}$ & O-1 & 112.3 & -14.7 \\
\hline & $\mathrm{C}-2$ & 67.2 & & $\mathrm{C}-2$ & 70.6 & 3.4 \\
\hline & $\mathrm{H}-3$ & 49.8 & & $\mathrm{H}-3$ & 36.0 & -13.8 \\
\hline & & & & $\mathrm{H}-4$ & 17.0 & \\
\hline \multirow[t]{6}{*}{$\left(\mathrm{CH}_{3}\right) \mathrm{HCO}$} & O-1 & 127.1 & $\left(\mathrm{CH}_{3}\right) \mathrm{H}=\mathrm{COH}^{+}$ & O-1 & 112.3 & -14.8 \\
\hline & $\mathrm{C}-2$ & 56.5 & & $\mathrm{C}-2$ & 60.9 & 4.5 \\
\hline & $\mathrm{H}-3$ & 51.1 & & $\mathrm{H}-3$ & 39.0 & -12.2 \\
\hline & C-4 & 75.8 & & $\mathrm{C}-4$ & 76.8 & 1.0 \\
\hline & $\mathrm{H}-5$ & 47.1 & & $\mathrm{H}-5$ & 40.9 & -6.2 \\
\hline & & & & H-6 & 17.5 & \\
\hline
\end{tabular}


Table 6. Continued

\begin{tabular}{ccccccc}
\hline System & Atom & Volume & System & Atom & Volume & Variation \\
\hline$\left(\mathrm{CH}_{3}\right)_{2} \mathrm{CO}$ & $\mathrm{O}-1$ & 126.3 & $\left(\mathrm{CH}_{3}\right)_{2} \mathrm{COH}^{+}$ & $\mathrm{O}-1$ & 110.9 & -15.4 \\
& $\mathrm{C}-2$ & 46.8 & & $\mathrm{C}-2$ & 50.8 & 3.9 \\
& $\mathrm{C}-3$ & 74.5 & & $\mathrm{C}-3$ & 75.6 & 1.2 \\
& $\mathrm{H}-4$ & 47.4 & & $\mathrm{H}-4$ & 42.0 & -5.4 \\
$\mathrm{H}_{2} \mathrm{CNH}$ & & & & $\mathrm{H}-5$ & 18.9 & \\
& $\mathrm{~N}-1$ & 132.4 & $\mathrm{H}_{2} \mathrm{CNH}_{2}{ }^{+}$ & $\mathrm{N}-1$ & 114.2 & -18.2 \\
& $\mathrm{C}-2$ & 75.9 & & $\mathrm{C}-2$ & 74.0 & -2.0 \\
& $\mathrm{H}-3$ & 48.1 & & $\mathrm{H}-3$ & 37.3 & -10.8 \\
& $\mathrm{H}-4$ & 33.3 & & $\mathrm{H}-4$ & 23.3 & -10.0 \\
$\left(\mathrm{CH}_{3}\right)_{\mathrm{HCNH}}$ & $\mathrm{N}-1$ & 132.2 & $\left(\mathrm{CH}_{3}\right) \mathrm{HCNH}_{2}{ }^{+}$ & $\mathrm{N}-1$ & 113.5 & -18.7 \\
& $\mathrm{C}-2$ & 63.6 & & $\mathrm{C}-2$ & 62.2 & -1.3 \\
& $\mathrm{H}-3$ & 49.8 & & $\mathrm{H}-3$ & 39.3 & -10.5 \\
& $\mathrm{C}-4$ & 73.9 & & $\mathrm{C}-4$ & 75.9 & 2.0 \\
& $\mathrm{H}-5$ & 47.5 & & $\mathrm{H}-5$ & 42.4 & -5.1 \\
& $\mathrm{H}-6$ & 33.5 & & $\mathrm{H}-6$ & 24.3 & -9.2 \\
& $\mathrm{~N}-1$ & 130.9 & $\left(\mathrm{CH}_{3}\right)_{2} \mathrm{CNH}_{2}{ }^{+}$ & $\mathrm{N}-1$ & 111.7 & -19.2 \\
& $\mathrm{C}-2$ & 53.0 & & $\mathrm{H}-2$ & 51.5 & -1.5 \\
& $\mathrm{C}-3$ & 72.7 & & $\mathrm{C}-3$ & 74.5 & 1.8 \\
& $\mathrm{H}-4$ & 47.9 & & $\mathrm{H}-4$ & 43.2 & -4.7 \\
& $\mathrm{H}-5$ & 34.2 & & $\mathrm{H}-5$ & 25.0 & -9.2 \\
\hline
\end{tabular}

The transferability of group properties within the QTAIM methodology has been studied previously for the case of terminal substituted alkanes. ${ }^{7,8}$ In the present article, the variation of the properties of the methyl group has been calculated for the neutral and protonated systems considered here (Table 7). The variation observed in all the parameters is very large, the maximum differences between the two extremes in the neutral cases being $921 \mathrm{~kJ} / \mathrm{mol}, 0.49 \mathrm{e}$, and 7.6 a.u. If the neutral and protonated cases are considered together the range of values obtained for the charge and volume is even larger. The effect is minimized when families of chemical compounds are considered independently, but in the neutral amines the energy difference is still up to $82 \mathrm{~kJ} / \mathrm{mol}$ (between methylamine and trimethylamine). 
Table 7. Properties of the methyl group in the molecules studied in the present Article (a.u.)

\begin{tabular}{lccclccc}
\hline & Energy & Charge & Volume & & Energy & Charge & Volume \\
\hline $\mathrm{CH}_{3} \mathrm{OH}$ & -39.55060 & 0.532 & 209.6 & $\mathrm{CH}_{3} \mathrm{OH}_{2}^{+}$ & -39.56798 & 0.701 & 193.0 \\
$\left(\mathrm{CH}_{3}\right)_{2} \mathrm{O}$ & -39.57393 & 0.538 & 208.9 & $\left(\mathrm{CH}_{3}\right)_{2} \mathrm{OH}^{+}$ & -39.58355 & 0.677 & 194.6 \\
$\mathrm{CH}_{3} \mathrm{NH}_{2}$ & -39.70820 & 0.334 & 213.1 & $\mathrm{CH}_{3} \mathrm{NH}_{3}^{+}$ & -39.65736 & 0.578 & 197.1 \\
$\left(\mathrm{CH}_{3}\right)_{2} \mathrm{NH}$ & -39.72599 & 0.333 & 212.8 & $\left(\mathrm{CH}_{3}\right)_{2} \mathrm{NH}_{2}^{+}$ & -39.67663 & 0.549 & 197.6 \\
$\left(\mathrm{CH}_{3}\right)_{3} \mathrm{~N}$ & -39.73941 & 0.333 & 211.1 & $\left(\mathrm{CH}_{3}\right)_{3} \mathrm{NH}^{+}$ & -39.69835 & 0.520 & 196.8 \\
$\left(\mathrm{CH}_{3}\right) \mathrm{HCO}$ & -39.87069 & 0.073 & 217.1 & $\left(\mathrm{CH}_{3}\right) \mathrm{HCOH}^{+}$ & -39.72781 & 0.430 & 199.6 \\
$\left(\mathrm{CH}_{3}\right)_{2} \mathrm{CO}$ & -39.89062 & 0.052 & 216.7 & $\left(\mathrm{CH}_{3}\right)_{2} \mathrm{COH}^{+}$ & -39.77581 & 0.346 & 201.7 \\
$\left(\mathrm{CH}_{3}\right) \mathrm{HCNH}$ & -39.88305 & 0.071 & 216.4 & $\left(\mathrm{CH}_{3}\right) \mathrm{HCNH}_{2}^{+}$ & -39.79134 & 0.340 & 203.1 \\
$\left(\mathrm{CH}_{3}\right)_{2} \mathrm{CNH}$ & -39.90149 & 0.043 & 216.5 & $\left(\mathrm{CH}_{3}\right)_{2} \mathrm{CNH}_{2}^{+}$ & -39.82268 & 0.287 & 204.1 \\
\hline
\end{tabular}

\section{Conclusions}

A theoretical study by QTAIM of the electron density properties of a series of neutral and protonated systems has been carried out. The effect of protonation on the systems is to produce an increase in the total molecular energy, which generates an increase in the atomic energy of the protonated heteroatom. This effect has been shown to reduce with an increasing number of methyl groups present in the molecule.

The charge redistribution produces an increase of the charge on the protonated atom for the case of oxygen, while the opposite is observed when nitrogen is protonated. The carbon atoms of the methyl groups became more negatively charged, but the overall result for the methyl group is an increase of the charge.

The molecular volume is reduced upon protonation of the system, and this reduction is proportional to the proton affinity of the system. At the atomic level, only the carbon atoms of the methyl groups increase in volume.

The results obtained for the methyl groups within the systems studied have been compared, showing large differences in their parameters, depending on the group that is attached.

\section{Acknowledgements}

Thanks are given to Dr. Cherif Mata for helpful comments and discussions. Financial support was provided by the Spanish DGI/MCYT (Project no. BQU2003-01251). 


\section{References}

1. Becke, A. D. J. Chem. Phys. 1993, 98, 5648. (b) C. Lee; Yang, W.; Parr, R. G. Phys. Rev. B 1988, 37, 785.

2. Hariharan, P. A.; Pople, J. A. Theor. Chim. Acta 1973, 28, 213.

3. Gaussian 98, Frisch, M. J.; Trucks, G. W.; Schlegel, H. B.; Scuseria, G. E.; Robb, M. A.; Cheeseman, J. R.; Zakrzewski, V. G.; Montgomery, J. A.; Stratmann, R. E.; Burant, J. C.; Dapprich, S.; Millam, J. M.; Daniels, A. D.; Kudin, K. N.; Strain, M. C.; Farkas, O.; Tomasi, J.; Barone, V.; Cossi, M.; Cammi, R.; Mennucci, B.; Pomelli, C.; Adamo, C.; Clifford, S.; Ochterski, J.; Petersson, G. A.; Ayala, P. Y.; Cui, Q.; Morokuma, K.; Malick, D. K.; Rabuck, A. D.; Raghavachari, K.; Foresman, J. B.; Cioslowski, J.; Ortiz, J. V.; Stefanov, B. B.; Liu, G.; Liashenko, A.; Piskorz, P.; Komaromi, I.; Gomperts, R.; Martin, R. L.; Fox, D. J.; Keith, T.; Al-Laham, M. A.; Peng, C. Y.; Nanayakkara, A.; Gonzalez, C.; Challacombe, M.; Gill, P. M. W.; Johnson, B. G.; Chen, W.; Wong, M. W.; Andres, J. L.; Head-Gordon, M.; Replogle, E. S.; Pople, J. A. Gaussian, Inc., Pittsburgh, PA, 1998.

4. Bader, R. F. W. Atoms in Molecules: A Quantum Theory; The International Series of Monographs of Chemistry; Halpen, J.; Green, M. L. H., Eds; Clarendon Press:Oxford, 1990.

5. Bieger-Konig, F. W.; Bader, R. F. W.; Tang, T. H. J. Comput. Chem. 1982, 3, 317.

6. NIST Standard Reference Database Number 69 - March 2003 Release, (http://webbook.nist.gov/chemistry/).

7. Cortés-Guzman, F.; Bader, R. F. W. J. Phys. Org. Chem. 2004, 17, 95.

8. Cortés-Guzman, F.; Bader, R. F. W. Chem. Phys. Lett. 2003, 379, 183. 